\title{
PENANGGULANGAN PENANGKAPAN IKAN SECARA TIDAK SAH (ILLEGAL FISHING) OLEH KAPAL IKAN ASING DI ZONA EKONOMI EKSKLUSIF INDONESIA
}

\author{
Melly Aida
}

Dosen Bagian Hukum Internasional Fakultas Hukum Unversitas Lampung

\begin{abstract}
Abstrak
Penangkapan ikan secara tidak sah ( illegal fishing ) oleh kapal ikan asing di wilayah Zona Ekonomi Eksklusif Indonesia ( ZEEI ) semakin tahun semakin meningkat. Seiring dengan kondisi tersebut negara menderita kerugian yang besar dari tindakan ini. Ada anggapan bahwa terjadinya hal tersebut karena kewenangan penegakan hukum oleh negara pantai ( Indonesia ) yang terbatas disebabkan ketentuan yang ada di dalam Konvensi Hukum Laut 1982 ( KHL 1982 ). Kemudian jika dilihat dari segi penegakan hukum oleh pemerintah, penanganan illegal fishing nampaknya masih memprihatinkan. Tulisan ini ingin mengkaji bagaimana kewenangan Indonesia dalam menanggulangi illegal fishing di wilayah ZEEI berdasar KHL 1982. Selain itu dalam tulisan ini juga ingin dikaji bagaimana penanggulangan yang dilakukan oleh pemerintah Indonesia terhadap tindak illegal fishing ini. Data dalam tulisan ini dicari dengan cara melakukan studi kepustakaan, artinya dengan cara mempelajari buku-buku, naskah-naskah yang berkaitan dengan permasalahan yang dibahas. Data yang didapat kemudian dikumpulkan lalu disistematisasi. Data yang sudah disistematisasi itu kemudian dijelaskan untuk dapat menjawab permasalahan yang diajukan. Hasil yang didapat dari pembahasan dalam tulisan ini adalah: Indonesia berdasar KHL 1982 mempunyai kewenangan yang tegas dalam menindak pelaku illegal fishing, namun dalam pelaksanaan penanggulangan illegal fishing di wilayah ZEE masih mengalami beberapa hambatan.
\end{abstract}

Kata-kata Kunci : Penanggulangan; Illegal Fishing; Kewenangan; Penegakan Hukum; Zona Ekonomi Eksklusif

\section{PENDAHULUAN}

Indonesia adalah negara kepulauan, wilayah Indonesia terdiri dari pulau-pulau besar maupun pulau-pulau kecil, dan hampir dua pertiga wilayah Indonesia merupakan laut. Kondisi geografis Indonesia yang demikian, membuat Indonesia harus turut aktif dalam forum internasional di bidang hukum laut, hal ini menyangkut kepentingan Indonesia baik politik, sosial, ekonomi, serta pertahanan keamanan.

Beberapa deklarasi hukum laut seperti Deklarasi Montevideo tentang hukum laut tahun 1970 dan deklarasi negara-negara Amerika Latin tentang hukum laut yang ditandatangani pada bulan Agustus di Lima menegaskan bahwa secara georafis, ekonomi, sosial, mempunyai hubungan yang erat antara tanah, dan orang-orang yang berdiam di darat, dan dibenarkan pemberian prioritas bagi penduduk dan orang-orang yang 
berdiam tersebut untuk memanfaatkan sumber daya alam di laut yang berdekatan pantainya. Kondisi seperti ini dialami oleh Indonesia yang menanggap bahwa daratan dan laut yang berada di antara dan megelilingi pulau-pulau adalah sebagai bagian dari kehidupan bangsa Indonesia dan milik seluruh bangsa Indonesia. ${ }^{1}$

Sebagai bangsa yang tinggal dan hidup pada wilayah yang sebagian besar terdiri dari wilayah laut, bangsa Indonesia perlu mengembangkan konsep geopolitik dan geostrategi sebagaimana yang tertuang dalam wawasan nusantara yang memandang seluruh wilayah daratan, lautan, dan udara di atasnya. Segenap penduduk serta seluruh sumber daya yang terkandung di dalamnya sebagai sesuatu yang terpadu. Laut memberikan peluang dan keuntungan yang besar bagi bangsa Indonesia dalm upaya memanfaatkan dan mendayagunakan secara optimal sumber daya alam di laut untuk pembangunan nasional Indonesia.

Konvensi Hukum Laut 1982 yang mulai berlaku sejak tanggal 16 Desember 1994 telah diratifikasi oleh Indonesia pada tanggal 31 Desember 1985 melalui Undang- Undang Nomor. 17 Tahun 1985 Tentang Ratifikasi Indonesia Terhadap United Nations Convention on the Law of the Sea 1982 ( selanjutnya disingkat UU No. 17 Tahun 1985 ). Konvensi ini memberikan kepada Indonesia wewenang yang lebih besar untuk mendayagunakan segenap sumber daya kelautan di wilayahnya sampai ke luar batas-batas wilayah negara yaitu di Zona Ekonomi Eksklusif (

${ }^{1}$ Frans E. Likadja, Bunga Rampai Hukum Laut Internasional, Bina Cipta, Bandung, 1978, hlm 63.
ZEE ) dan landas kontinen. Dengan UU No. 17 Tahun 1985 ini berarti Indonesia telah menundukkan diri pada konvensi ini, sehingga segala kebijakan Indonesia di bidang kelautan harus sesuai dengan ketentuan konvensi tersebut. Selain itu, dengan diratifikasinya Konvensi Hukum Laut 1982, maka wilayah Indonesia menjadi semakin luas yaitu $8.193 .250 \mathrm{~km}^{2}$ yang terdiri dari $2.027 .087 \mathrm{~km}^{2}$ daratan dan 6.166.165. $\mathrm{km}^{2}$ wilayah perairan. Dari luas perairan tersebut, meliputi 0,3 juta $\mathrm{km}^{2}$ laut territorial 2,8 juta $\mathrm{km}^{2}$ perairan kepulauan dan ZEE seluas 2,7 juta $\mathrm{km}^{2}{ }^{2}$

Salah satu bagian dari konvensi ini adalah mengenai ZEE yang diatur pada bagian ke 5, Pasal 55 sampai 75. Adapun hak-hak negara pantai pada ZEE adalah sebagai berikut : ${ }^{3}$

1. Hak berdaulat untuk mengadakan eksplorasi dan eksploitasi, konservasi dan pengurusan sumber kekayaan alam hayati dan non hayati dari dasar laut dan tanah di bawahnya.

2. Hak berdaulat atas kegiatankegiatan eksplorasi dan eksploitasi seperti produksi air dan angin.

3. Yurisdiksi untuk pendirian dan pemanfaatan pulau buatan, instalasi bangunan, riset ilmiah kelautan, perlindungan, dan pembinaan lingkungan maritim.

Di dalam melaksanankan hakhak dan kewajibannya menurut konvensi di ZEE, negara pantai harus

2 Mustafa Abdullah, Aspek Hukum Penerapan KUHAP DI Perairan Indonesia dan Zona Ekonomi Eksklusif, BPHN, Jakarta, 1998, hlm 1-2.

${ }^{3}$ Chairul Anwar, Horizon Baru Hukum Laut Internasional, Rhineka Cipta, Jakarta, 1988, hlm 45 . 
memperhatikan hak-hak dan kewajiban negara lain dan bertindak sesuai dengan ketentuan konvensi. Negara pantai memiliki hak penegakan hukum dan peraturan perundang-undangannya di ZEE sebagai berikut :

1. Menaiki, melakukan inspeksi, menahan, dan mengajukan ke pengadilan kapal beserta awakawaknya.

2. Bahwa kapal beserta awaknya yang ditahan akan segera dibebaskan setelah dilakukan pembayaran uang jaminan.

3. Negara pantai dalam melakukan penahanan kapal-kapal asing harus segera memberi tahu negara bendera kapal atas tindakan yang diambil dan denda yang dikenakan.

4. Dalam hal tidak terdapat perjanjian internasional, negara pantai atas pelanggaran hukum atau perundang-undangan penangkapan ikan dari ZEE tidak dibenarkan melakukan hukuman penjara.

Peraturan perundang-undangan yang berkaitan dengan pelaksanaan hak berdaulat di Indonesia di Zona Ekonomi Eksklusif Indonesia (ZEEI) adalah Undang-Undang Nomor. 5 Tahun 1983 Tentang Zona Ekonomi Eksklusif Indonesia (UndangUndang ZEEI) dan Undang-Undang Nomor 31 Tahun 2004 Tentang Perikanan $^{4} \quad$ (Undang-Undang Perikanan 2004), Peraturan Pemerintah Nomor 15 Tahun 1984 Tentang Pengelolaan Sumber Daya Alam Hayati Di Zona Ekonomi Eksklusif Indonesia. Peraturan perundang-undangan di atas memuat

4 Undang-Undang Nomor 31 Tahun 2004 Tentang Perikanan merupakan pengganti dari Undang-Undang Nomor 9 Tahun 1985 Tentang Perikanan. pula ketentuan penegakan hukum yang berkaitan dengan pencurian ikan oleh pihak asing di ZEEI. Menurut pengamatan penulis semua ketentuan tentang penegakan hukum di ZEEI telah sesuai dengan ketentuan Konvensi Hukum Laut 1982.

Peraturan perundang-undangan di atas hanya mencantumkan satu sanksi berupa sanksi pidana denda, pidana denda ini menimbulkan suatu permasalahan tersendiri. Apabila timbul permasalahan bahwa yang bersangkutan tidak mau atau tidak mempunyai dana untuk membayar denda yang dibebankan kepadanya, langkah apa yang dapat diambil untuk dipenuhinya denda tersebut atau sampai kapan batas waktu yang harus ditentukan untuk memenuhi denda tersebut, hal ini menyangkut orang asing (terdakwa) yang harus tetap berada di Indonesia menunggu denda tersebut dipenuhi. ${ }^{5}$ Ketentuan pidana dalam UU No. 5/1983 tentang ZEEI tidak sama dengan ketentuan perundang-undangan yang lain. Dalam Undang-undang tentang ZEEI ini, pidana denda yang dijatuhkan oleh hakim tidak dapat diganti dengan hukuman kurungan. ${ }^{6}$

Kasus pencurian ikan oleh kapal asing di ZEEI semakin meningkat, dan hal ini secara ekonomis merugikan Indonesia. Menurut laporan penelitian proyek kerjasama Badan Penelitian dan Pengembangan Masalah Politik Luar Negeri Departemen Luar Negeri dengan Pusat Studi Wawasan Nusantara dan Pembangunan tahun 1993-1994 disebutkan bahwa untuk

\footnotetext{
${ }^{5}$ P. Joko Subagyo, Hukum Laut Indonesia, Rhineka Cipta, Jakarta, 1993, hlm 98.

${ }^{6}$ Hotman Sitorus, Mengkaji Ulang Sanksi Pidana Di Zona Ekonomi Eksklusif, dimuat dalam Harian Neraca, Kamis 4 Maret 1993.
} 
di ZEE kerugian yang diderita tiap tahunnya paling sedikit mencapai satu triliun rupiah.

Hal ini menunjukkan kepada kita betapa penanganan terhadap kasus-kasus perikanan di Indonesia sangat memprihatinkan. Padahal akibat lumpuhnya penegakan hukum di bidang perikanan ini telah mengakibatkan kerugian besar bagi negara. Kerugian akibat pencurian ikan pada tahun 2004 diperkirakan berkisar antara 1 juta sampai 1,5 juta ton per tahun atau setara dengan dua miliar dollar AS sampai empat miliar dollar AS. Kerugian tersebut belum termasuk kerusakan biota laut sebagai akibat dari penangkapan ikan dengan menggunakan pukat harimau dan berbagai alat tangkap berteknologi canggih lainnya. ${ }^{7}$

Uraian-uraian tersebut di atas menunjukkan terbatasnya kewenangan Indonesia dalam menanggulangi penangkapan ikan secara tidak sah (illegal fishing) oleh kapal ikan asing sebagaimana diatur dalam Konvensi Hukum Laut 1982, sehingga lemahnya penegakan hukum yang dilakukan Indonesia sebagai negara peratifikasi konvensi dalam menanggulangi illegal fishing di wilayah ZEEI. Berdasarkan latar uraian tersebut, permasalahannya adalah "bagaimanakah kewenangan dan upaya-upaya yang dilakukan oleh Indonesia sebagai negara peratifikasi KHL 1982 dalam menanggulangi tindak illegal fishing oleh kapal ikan asing di ZEEI ?"

\section{PEMBAHASAN}

\subsection{Ratifikasi Konvensi Hukum Laut 1982}

7 Rusmana, Pengadilan Perikanan Mampukah Menjadi Terobosan, Solusi hukum.com, 30 Oktober 2004.
Menurut F. Sugeng Istanto ratifikasi adalah perbuatan negara yang dalam taraf internasional menetapkan persetujuannya untuk terikat pada suatu perjanjian internasional yang ditandatangani oleh perutusannya. ${ }^{8}$ Konvensi Wina 1969 memuat definisi mengenai ratifikasi, menurut Konvensi Wina 1969 bahwa ratifikasi, penerimaan, pengesahan, dan aksesi dalam setiap kasus diartikan sebagai tindakan internasional apapun namanya di mana suatu negara dalam taraf internasional membuat kesepakatannya untuk mengikatkan diri pada suatu perjanjian. ${ }^{9}$

Pelaksanaan ratifikasi tergantung hukum nasional negara yang bersangkutan. Dasar pembenaran adanya ratifikasi itu antara lain ialah bahwa negara berhak untuk meninjau kembali hasil perundingan perutusannya sebelum menerima kewajiban yang ditetapkan dalam perjanjian internasional yang bersangkutan dan bahwa negara tersebut mungkin memerlukan penyesuaian hukum nasionalnya dengan ketentuan-ketentuan yang diperjanjikan. Namun demikian hukum internasional tidak mewajibkan negara, yang perutusannya telah menandatangani hasil perundingan yang dilakukan, menurut hukum ataupun moral, untuk meratifikasi persetujuan tersebut. Tidak adanya kewajiban itu disebabkan karena negara adalah berdaulat. ${ }^{10}$ Akibat hukum ratifikasi suatu konvensi internasional adalah bahwa negara peratifikasi terikat

\footnotetext{
${ }^{8}$ F. Sugeng Istanto, Hukum Internasional, Penerbitan Universitas Atma Jaya Yogyakarta, Yogyakarta, 1994, hlm 68.

9 Pasal 2 ayat (1) b Konvensi Wina Tahun 1969.

${ }^{10}$ F. Sugeng Istanto, Loc.cit.
} 
kepada ketentuan-ketentuan konvensi yang diratifikasi tersebut, sehingga peraturan perundang-undangan negara tersebut harus disesuaikan dengan konvensi.

Berkaitan dengan Konferensi Hukum Laut PBB III, yang menghasilkan Konvensi Hukum Laut 1982 ( KHL 1982 ). Konvensi ini terbuka untuk penandatanganan bukan saja oleh negara, namun juga lembaga-lembaga yang diakui PBB asal saja mereka ikut serta dalam konperensi dan mampu melaksanakan perjanjian internasional, yakni negara-negara yang secara penuh telah berpemerintahan sendiri namun belum merdeka secara penuh. ${ }^{11}$ Annex IX Konvensi ini juga menyatakan konvensi dapat juga ditandatangani oleh organisasiorganisasi internasional. Konvensi ini membutuhkan ratifikasi dan terbuka untuk aksesi.

Sesuai dengan Pasal 308 KHL 1982, bahwa konvensi akan mulai berlaku dua belas bulan setelah dipenuhinya jumlah ratifikasi sebanyak 60 negara. KHL 1982 mulai berlaku sejak tanggal 16 Nopemeber 1994, karena syarat yang ditentukan oleh Pasal 308 tersebut telah dipenuhi oleh negara Guyana pada tanggal 16 Nopember $1993 .^{12}$

Keberadaan KHL 1982 mempunyai pengaruh bagi negara pantai maupun negara lainnya.

11 Pasal 305 Konvensi Hukum Laut PBB 1982.

12 Etty R. Agoes, Pemanfaatan Sumber Daya Kelautan dan Tantangan Liberalisasi Ekonomi Dalam Menghadapi Perdagangan Bebas, makalah disampaikan pada seminar Konvensi Nasional Pembangunan Benua Maritim Indonesia Dalam Rangka Mengaktualisasikan Wawasan Nusantara, Ujung Pandang, tanggal 18-19 Desember 1996.
Adapun pengaruhnya adalah sebagai berikut : ${ }^{13}$

1. Dapat membantu negara pantai menjamin kepentingannya

2. Memberikan kesempatan kepada negara pantai melakukan perluasan wilayah laut

3. Memperluas tanggung jawab negara pantai terhadap lautan

4. Berkurangnya wilayah laut bebas, dan menjadi laut territorial

5. Mendukung pelestarian lingkungan laut yang harus dijaga oleh hukum nasional suatu negara

6. Mengurangi kebebasan yang semula ada bagi pengelola lautan.

Sebagai akibat dari ratifikasi Indonesia terhadap KHL 1982, maka wilayah perairan yang tunduk di bawah kedaulatan Indonesia mendapat pengakuan internasional sebagai berikut : ${ }^{14}$

1. Laut antara pulau-pulau Indonesia yang dikelilingi oleh garis-garis pangkal nusantara dan wilayah laut selebar 12 mil yang megelilinginya diakui sebagai wilayah Republik Indonesia.

2. Hak-hak berdaulat Indonesia atas kekayaan alam yang terkandung dalam perairan ZEE selebar 200 mil dari garis-garis pangkal nusantara, dan atas kekayaan alam landas kontinen di dasar laut sampai batas terluar batas kontinen Indonesia.

\footnotetext{
${ }^{13}$ P. Joko Subagyo, Opcit, hlm 36.

14 Departemen Kelautan dan Perikanan RI, Kampanye Kelautan dan Perikanan ( Paradigma Pembangunan Kelautan dan Perikanan ), Edisi Perdana, Yayasan Bina Mulia, Jakarta , 2000, hlm 71.
} 


\subsection{Ketentuan Mengenai Zona Ekonomi Eksklusif Dalam Konvensi Hukum Laut 1982}

\section{a. Pengertian Zona Ekonomi Eksklusif}

Di dalam KHL 1982 ZEE diatur dalam bagian ke -5 yang terdiri dari 21 pasal, yaitu pasal 55 sampai dengan pasal 75. Sebanyak 15 pasal mengatur masalah perikanan di ZEE negara pantai.

Menurut KHL 1982, yang dimaksud dengan ZEE adalah :

"The Exclusive Economic Zone is an area beyond and adjacent to the territorial sea, subject to the specific legal regime esthablished in this part under which the rights and jurisdiction of the coastal state and the rights and freedoms of other States are governed by the relevant provisions of this Convention". ${ }^{15}$

Maksudnya adalah ZEE adalah suatu jalur di luar dan berbatasan dengan laut wilayah, yang tunduk kepada regim khusus sebagaimana yang ditetapkan pada bagian ini yang meliputi yurisdiksi negara pantai dan hak-hak serta kebebasan-kebebasan negara-negara lain yang ditentukan sesuai dengan konvensi ini.

Penenentuan batas dari ZEE antara negara-negara yang pantainya bersambungan atau berhadapan dapat dilakukan dengan perjanjian menurut hukum internasional guna memperoleh pemecahan yang adil dan merata. Dalam hal tidak tercapainya kesepakatan dalam waktu yang layak, negara-negara tersebut dapat memecahkan hal ini melalui prosedur penyelesaian

\footnotetext{
${ }^{15}$ Pasal 55 Konvensi Hukum Laut PBB.
}

perselisihan konvensi ini. Di dalam ZEE diatur hak-hak negara pantai di satu pihak serta hak-hak dan kebebasan negara lain di lain pihak. ${ }^{16}$

\section{b. Konservasi dan Eksploitasi di Zona Ekonomi Eksklusif}

Berdasar Pasal 56 KHL 1982, negara pantai dalam ZEE mempunyai hak-hak berdaulat untuk keperluan eksplorasi dan eksploitasi, konservasi dan pengelolaan sumebr kekayaan alam, baik hayati maupun non hayati, dari perairan di atas dasar laut dan tanah di bawahnya dan berkenaan dengan kegiatan lain untuk keperluan eksplorasi dan eksploitasi zona tersebut, seperti produksi energi dari air, arus dan angin.

Yurisdiksi di ZEE terbatas pada hak untuk melakukan eksploitasi sumber kekayaan alam yang dikandungnya, dengan tetap mengakui adanya status lain dari perairan tersebut sebagai laut bebas, untuk kegiatan-kegiatan yang bukan termasuk ke dalam pemanfaatn kekayaan alam. Dengan perkataan lain, yurisdiksi yang diberikan oleh konvensi hanya terbatas pada hakhak ekonomi negara pantai atas kekayaan alamnya. Sedangkan di bidang pelayaran dan pemasangan kabel dan pipa di bawah laut, tetap merupakan laut bebas.

Selain yurisdiksi terhadap kekayaan alam yang dikandung di ZEE, kegiatan-kegiatan yang sesungguhnya memiliki keterkaitan dengan eksistensi dari kekayaan tersebut, konvensi mengakui adanya

16 Syahmin A.K, Beberapa Perkembangan dan Masalah Hukum Laut Internasional ( Sekitar Penegakan Hukum di Perairan Yurisdiksi Nasional Dewasa Ini ), Bina Cipta, Bandung, hlm 57. 
$\begin{array}{llr}\text { yurisdiksi } & \text { yang } & \text { berkaitan } \\ \text { sebagaimana } & \text { ditentukan } & \text { dalam }\end{array}$ ketentuan yang relevan dengan konvensi ini berkenaan dengan : (i) pembuatan dan pemakaian pulau buatan, instalasi dan bangunan, (ii) riset ilmiah dan kelautan; dan (iii) perlindungan dan pelestarian lingkungan laut ditambah dengan hak dan kewajiban lain sebagaimana ditentukan oleh konvensi. Namun dalam melaksanakan hak-hak dan memenuhi kewajibannya berdasarkan konvensi ini dalam ZEE, negara pantai harus memperhatikan hak-hak negara lain, dan harus bertindak sesuai dengan ketentuan konvensi.

Mengenai hak-hak negara lain ditegaskan dalam pasal 58 yang menyatakan bahwa semua negara, baik negara yang berpantai ( coastal state ) atau negara tidak berpantai ( landlocked state ) dengan tunduk pada ketentuan yang relevan dengan konvensi menikmati kebebasan pelayaran dan penerbangan, serta kebebasan meletakkan kabel dan pipa bawah laut, dan penggunaan laut lain yang sah menurut hukum internasional.

Sebagaimana dijelaskan di atas, bahwa sesungguhnya yurisdiksi negara pantai yang berlaku di ZEE sifatnya terbatas, dan kebebasankebebasan yang berlaku di laut lepas masih melekat dalam hal-hal tertentu. Hal ini dimaksudkan agar pemanfaatan kekayaan alam di ZEE jangan sampai merusak lingkungan hidup sumber kekayaan alam hayati di perairan tersebut. Mengingat sumber daya alam hayati seperti ikan sebenarnya tidak dapat dibatasi oleh suatu batasan tertentu dan mempunyai sifat berpindah-pindah, sehingga kepentingan eksploitasi sumber tersebut oleh suatu negara lain, terutama negara- negara yang berdekatan baik berhadapan maupun berdampingan.

Oleh karena itu, konvensi mewajibkan negara pantai melakukan hal-hal sebagai berikut $:^{17}$

1. Negara pantai harus menentukan jumlah tangkapan yang diperbolehkan (Total Allowable Catch-TAC ) dalam ZEE nya.

2. Dengan memperhatikan bukti ilmiah terbaik dan tersedia baginya harus menjamin dengan mengadakan tindakan koservasi dan pengelolaan yang tepat sehingga pemeliharaan sumber kekayaan alam hayati di ZEE tidak dibahayakan oleh eksploitasi yang berlebihan. Perlu kerja sama antara negara pantai dan organisasi internasional untuk tujuan ini.

3. Tindakan demikian juga bertujuan untuk memelihara dan memulihkan populasi jenis yang dapat dimanfaatkan pada tingkat yang dapat menjamin hasil maksimum yang lestari, sebagaimana ditentukan oleh faktor ekonomi dan lingkungan yang relevan, termasuk kebutuhan masyarakat nelayan daerah pantai dan kebutuhan khusus negara berkembang dan dengan memperhatikan pola penangkapan ikan, saling ketergantungan persediaan jenis ikan dan standar minimum internasional yang dianjurkan secara umum, baik di tingkat sub regional, regional, maupun global.

4. Dalam mengambil tindakan demikian, negara pantai harus

17 H.A.S. Natabaya,et. All, Aspek-Aspek Hukum Pengelolaan Perikanan Di Perairan Nasional Zona Ekonomi Eksklusif Indonesia, BPHN, Jakarta, 1993, hlm 34. 
memperhatikan akibat-akibat terhadap jenis-jenis yang berhubungan atau tergantung pada jenis yang dimanfaatkan dengan tujuan untuk memelihara atau memulihkan populasi jenis yang berhubungan atau tergantung demikian di atas tingkat reproduksinya dapat sangat terancam.

5. Keterangan ilmiah yang tersedia, statistik penagkapan dan usaha perikanan, serta data lainnnya yang relevan dengan konservasi persediaan jenis ikan harus disumbangkan dan dipertukarkan secara teratur melalui organisasi internasional yang berwenang dan dengan peran serta semua warga negara yang berkepentingan, termasuk warga negaranya diperbolehkan menangkap ikan di ZEE negara pantai yang bersangkutan.

Pasal 62 mengaharuskan negara pantai untuk menggalakkan pemanfaatan sumber kekayaan hayati di ZEE- nya. Untuk itu negara pantai diharuskan menetapkan kemampuan memanen sumber kekayaan hayati tersebut, dan apabila kemampuan tersebut tidak cukup untuk memanen jumlah tangkapan yang dibolehkan, maka kapal-kapal ikan asing harus diberi akses di ZEE-nya agar dapat mengeksploitasi kelebihan jumlah tangkapan yang dibolehkan. Jaminan pemberian akses kepada kapal-kapal ikan asing harus dengan perjanjian dan dengan memperhatikan beberapa faktor, serta khususnya hak-hak negara khusus yang tidak berpantai dan secara geografis tidak beruntung (untuk yang terakhir ini diartikan sebagai negara-negara yang makanannya tergantung kepada ZEE negara tetangganya dan negaranegara yang tidak memiliki ZEE- nya sendiri). Kapal-kapal ikan asing yang mempunyai hak akses pada ZEE suatu negara pantai harus mentaati peraturan perundangundangan negara pantai yang bersangkutan, yang dapat berisikan kewajiban-kewajiban dan persyaratan-persyaratan mengenai berbagai macam hal, seperti perijinan, imbalan keuangan, kuota, tindakan-tindakan konservasi, informasi, riset, peninjau, pendaratan tangkapan, persetujuan-persetujuan kerja sama, dan lain sebagainya. ${ }^{18}$

Apabila suatu cadangan ikan berada dalam dua ZEE negara pantai atau lebih, negara-negara yang bersangkutan harus membuat persetujuan untuk langkah-langkah konservasinya. Apabila suatu cadangan ikan berada di ZEE dan di luar itu, negara pantai dan negaranegara yang menangkap cadangan ikan yang sama di luar ZEE mempunyai kewajiban yang sama. ${ }^{19}$

Di dalam ZEE nya, suatu negara pantai dapat mengambil tindakan-tindakan untuk menjamin ditaatinya peraturan perundangundangan yang telah dikeluarkannya, termasuk untuk menghentikan, memeriksa, menahan dan menuntutnya secara hukum. Namun demikian, kapal yang ditahan harus dibebaskan setelah dibayarkan uang jaminan. Pada dasarnya negara pantai tidak boleh mengenakan pemenjaraan atau hukuman badan lainnya terhadap pelanggaranpelanggaran yang dilakukan di ZEEnya. ${ }^{20}$

\footnotetext{
18 Albert W. Koers, Konvensi Perserikatan Bangsa-Bangsa Tentang Hukum Laut Suatu Ringkasan, diterjemahkan oleh Rudi M. Rizki dan Wahyuni Bahar, Gadjah Mada University Press, Yogyakarta, 1994, hlm 36.

${ }^{19}$ Pasal 63 KHL PBB 1982.

${ }^{20}$ Pasal 73 KHL PBB 1982.
} 


\subsection{Tinjauan Umum Tentang Penanggulangan Penangkapan Ikan Secara Tidak Sah ( Illegal Fishing ) Oleh Kapal Ikan Asing Di Zona Ekonomi Eksklusif Indonesia}

\section{a. Pengertian Penangkapan Ikan Secara Tidak Sah (Illegal Fishing)}

Penangkapan ikan secara tidak sah (illegal fishing) adalah kapal perikanan yang melakukan penangkapan ikan tanpa ijin dari Pemeintah Republik Indonesia di wilayah pengelolaan perikanan Indonesia. Berdasar pasal 5 UndangUndang No. 31 Tahun 2004 tentang Perikanan (UU Perikanan 2004), disebutkan bahwa wilayah pengelolaan perikanan Indonesia meliputi :

1. Perairan Indonesia;

2. ZEEI;

3. Sungai, danau, waduk, rawa, dan genangan air lainnya yang dapat diusahakan serta lahan pembudidayaan ikan yang potensial di wilayah Republik Indonesia.

Sesuai dengan masalah yang dibahas dalam tulisan ini, hanya terbatas pada penangkapan ikan secara tidak sah di wilayah ZEEI. Maka yang dibahas adalah pengertian penangkanp ikan yang disebutkan dalam UU No. 5 tahun 1983 tentang ZEEI.

Dalam pasal 16 ayat (1) UU No. 5 tahun 1983 disebutkan bahwa "Melakukan penangkapan ikan di ZEEI tanpa ijin dipidana dengan pidana denda setinggi-tingginya Rp 225.000.000". Selanjutnya pasal 5 ayat (1) menetapkan bahwa barang siapa melakukan eksplorasi dan atau eksploitasi sumber daya alam atau kegiatan-kegiatan lainnya untuk eksplorasi dan eksploitasi ekonomis seperti pembangkitan tenaga dari air, arus dan angin di ZEEI, harus berdasarkan izin dari Pemerintah Republik Indonesia dan dilaksanakan menurut syarat-syarat perizinan atau persetujuan internasional tersebut.

Sementara itu, penangkapan ikan secara tidak sah menurut International North Pacific Fisheries Comission ( INPC) adalah sebagai berikut :21

"Illegal and unetichal fishing activity included (1) under reporting catch and by catch and keeping double sets of fishing logs, (2) misreporting the names, numbers, and location of fishing vessels, (3) unplugging, breaking or loosing transponders to avoid location detection, harassing monitoring personnel, (5) illegally fishing in the EEZ of other states, (6) using squid driftnet vessels to illegally catch salmon in north pacific in violation of the flag states international agreement as well as customary law, (7) transshipping illegal catches at sea or processing them into fish meal at sea so they can not be identified, (8) reflagging vessels to circumvent treaty obligation".

Berdasarkan uraian tersebut dapat disimpulkan bahwa penangkapan ikan secara tidak sah meliputi hal-hal sebagai berikut: (1) tanpa ijin dari pemerintah negara, (2) memalsukan serta menggandakan buku log perikanan, (3) tidak melaporkan nama, jumlah dan posisi kapal, (4) menyiksa petugas

\footnotetext{
${ }^{21}$ Lihat www. Earthrust.org
} 
pengawas, (5) di wilayah ZEE negara lain, (6) melanggar persetujuan internasional tentang ketentuan bendera kapal dan hukum kebiasaan internasional, (7) mengganti kapal atau memproses ikan di laut agar tidak dapat diidentifikasi, mengganti bendera kapal guna menghindari kewajiban-kewajiban perjanjian.

\section{b. Zona Ekonomi Eksklusif Indonesia}

Berdasar Pasal 2 UU No. 5 tahun 1983 Tentang ZEEI, yang dimaksud dengan ZEEI adalah suatu jalur di luar dan berbatasan dengan laut wilayah Indonesia sebagaimana ditetapkan berdasarkan undangundang yang berlaku tentang perairan Indoensia yang meliputi dasar laut, tanah di bawahnya, dan air di atasnya dengan batas terluar 200 mil laut diukur dari garis pangkal laut wilayah Indonesia.

KHL 1982 telah memberikan kepada Indonesia hak berdaulat untuk eksploitasi dan eksplorasi sumber daya alam yang terdapat di ZEE dan yurisdiksi yang berkaitan dengan pelaksanaan hak berdaulat tersebut, selain itu Indonesia berkewajiban untuk menghormati hak-hak negara lain antara lain kebebasan pelayaran dan penerbangan, serta kebebasan untuk pemasangan kabel dan pipa bawah laut di ZEEI khususnya yang berkaitan dengan pemanfaatan sumber daya alam hayati di ZEEI, maka negara lain dapat ikut serta memanfaatkan sumber daya alam hayati tersebut.

Di Indonesia, sebagaimana telah ditetapkan dalam UU No. 5 Tahun 1983 bahwa baik perorangan maupun perusahaan, baik pemerintah atau swasta yang melakukan kegiatan eksplorasi atau eksploitasi sumber daya alam atau kegiatan-kegiatan lainnya untuk eksplorasi dan eksploitasi ekonomis seperti pembangkitan tenaga dari air, arus dan angina di ZEEI, harus berdasarkan ijin dari Pemerintah Republik Indonesia atau persetujuan internasional dengan pemerintah Republik Indonesia dan dilaksanakan menurut syarat-syarat perijinan atau persetujuan internasional tersebut. Maksudnya ialah kegiatan untuk eksplorasi atau eksploitasi ekonomis tersebut yang dilakukan oleh Warga Negara Indonesia ( WNI ) harus berdasarkan ijin dari pemerintah Republik Indonesia, sedangkan kegiatan yang dilakukan oleh negara asing, orang atau badan hukum asing harus berdasarkan persetujuan internasional dan dicantumkan hakhak dan kewajiban-kewajiban yang harus dipatuhi oleh mereka yang melakukan kegiatan eksplorasi atau eksploitasi di zona tersebut, antara lain kewajiban membayar pungutan kepada pemerintah Republik Indonesia.

Indonesia sebagai negara yang mempunyai ZEE yang cukup luas, memiliki potensi perikanan yang melimpah. Oleh karena itu, Indonesia telah menetapkan beberapa kebijakan berkaitan dengan hak-hak Indonesia di bidang perikanan di wilayah ZEEI.

\section{c. Kebijakan Perikanan di Zona Ekonomi Eksklusif Indonesia}

Sebagaimana telah disebutkan di atas bahwa di bidang perikanan negara pantai mempunyai hak untuk mengatur tentang pengelolaan perikanan dalam rangka eksploitasi dan eksplorasi sumber kekayaan alam di ZEE nya. Oleh karena itu 
sebagai implementasi dari hak berdaulat tersebut pemerintah Indonesia telah menetapkan kebijakan-kebijakan yang berkaitan dengan pengelolaan perikanan di ZEEI.

Prinsip-prinsip yang dianut oleh perundang-undangan tentang perikanan Indonesia sebagai wujud kebijakan Indonesia adalah sebagai berikut :

1. ZEEI adalah wilayah pengelolaan perikanan Indonesia. Pasal 5 UU Perikanan 2004 menyatakan bahwa wilayah pengelolaan perikanan Indonesia meliputi :

a. perairan Indonesia;

b. ZEEI;

c. Sungai, danau, waduk, rawa, dan genangan air lainnya yang dapat diusahakan serta lahan pembudidayaan ikan yang potensial di wilayah Republik Indonesia.

2. ZEEI adalah jalur di luar dan berbatasan dengan laut wilayah Indonesia sebagaimana ditetapkan berdasarkan undangundang yang berlaku tentang perairan Indonesia yang meliputi dasar laut, tanah di bawahnya dan air di atasnya dengan batas terluar 200 mil laut diukur dari garis pangkal laut wilayah Indonesia. 22

3. Di ZEEI, Indonesia mempunyai dan melaksanakan hak berdaulatnya atas pengelolaan dan konservasi sumber daya alam hayati. $^{23}$

4. ZEEI adalah penting untuk mendukung perwujudan wawasan nusantara dalam rangka meningkatkan

${ }^{22}$ Pasal 2 Undang-Undang No. 5 Tahun 1983.

${ }^{23}$ Pasal 4 Undang-Undang No. 5 Tahun 1983. kesejahteraan bangsa Indonesia dengan memanfaatkan segenap sumber daya alam baik hayati maupun no hayati yang terdapat di ZEEI.

5. ZEEI merupakan potensi yang memberikan kemungkinan sangat besar untuk dapat dimnafaatkan secara langsung dan sekaligus berfungsi sebagai pendukung sumber daya perikanan di seluruh perairan Indonesia. ${ }^{24}$

6. Pemanfaatan yang sebesarbesarnya daripada sumber alam hayati di ZEEI harus diarahkan untuk mengembangkan usaha perikanan Indonesia. $^{25}$

7. Hak berdaulat tentang pengelolaan dan konservasi sumber daya alam hayati dilaksanakan menurut persetujuan-persetujuan antara Indonesia dengan negara-negara tetangga dan ketentuan-ketentuan hukum internasional yang berlaku. $^{26}$

8. Usaha perikanan di wilayah pengelolaan perikanan Republik Indonesia hanya boleh dilakukan oleh WNI atau badan hukum Indonesia. Pengecualian terhadap hal ini hanya dapat diberikan kepada orang atau badan hukum asing yang melakukan usaha penangkapan ikan di ZEEI, sepanjang hal tersebut menyangkut kewajiban Negara Republik Indonesia berdasarkan persetujan internasional atau ketentuan hukum internasional yang berlaku. ${ }^{27}$

\footnotetext{
${ }^{24}$ Konsiderans Peraturan Pemerintah No. 15 Tahun 1984.

${ }^{25}$ Konsiderans Peraturan Pemerintah No. 15 Tahun 1984.

${ }^{26}$ Pasal 4 ayat (2) Undang-Undang No. 5 Tahun 1983.

27 Pasal 29 Undang-Undang No. 31 Tahun 2004.
} 
9. Dalam rangka meningkatkan kemampuannya untuk memanfaatkan sumber daya alam hayati di ZEEI, orang atau badan hukum Indonesia yang bergerak di bidang usaha perikanan Indonesia dapat mengadakan kerja sama dengan orang atau badan hukum asing dalam bentuk usaha patungan atau bentuk kerja sama lainnya menurut peraturan perundang-undangan yang berlaku. ${ }^{28}$

10. Orang atau badan hukum asing dapat diberi kesempatan melakukan penangkapan ikan di ZEEI sepanjang orang atau badan hukum Indonesia yang bergerak di bidang usaha perikanan Indonesia belum dapat sepenuhnya memanfaatkan JTB (Jumlah Tangkapan Yang Diperbolehkan ). ${ }^{29}$

11. Pemberian ijin kepada orang atau badan hukum asing untuk menangkap ikan di ZEEI dapat diberikan setelah diadakan persetujuan antara pemerintah Republik Indonesia dengan pemerintah negara asing bersangkutan. Izin hanya diberikan apabila kebangsaan kapal perikanan atau yang dipergunakan sama dengan kebangsaan orang atau badan hukum asing yang bersangkutan.

12. Ijin penangkapan ikan bagi orang atau badan hukum asing di ZEEI diberikan dalam bentuk Surat Ijin Penangkapan Ikan yang dikeluarkan oleh Menteri

\footnotetext{
${ }^{28}$ Pasal 2 ayat (3) Peraturan Pemerintah No. 15 Tahun 1984.

29 Pasal 3 Peraturan Pemerintah No. 15 Tahun 1984.
}

Pertanian atau pejabat yang ditunjuk olehnya. ${ }^{30}$

13. Orang atau badan hukum asing yang telah mendapat ijin menangkap ikan di ZEEI menurut ketentuan Peraturan Pemerintah ini wajib menunjuki perusahaan yang berbadan hukum Indonesia yang disetujui oleh Menteri Pertanian atau pejabat yang ditunjuk olehnya untuk mewakili kepentingankepentingannya. ${ }^{31}$

\section{d. Penegakan Hukum Di Zona Ekonomi Eksklusif Indonesia}

Pada umumnya negara pantai memandang hal yang menyangkut pengawasan kapal perikanan asing sebagai masalah penting. Hal ini biasanya dijelmakan di dalam perjanjian bilateral perikanan yaitu pasal yang mengatur prosedur penegakan hukum. ${ }^{32}$ Ketentuan dari Pasal 62 ayat (4) KHL 1982 menentukan bahwa warga negara dari negara asing harus mernatuhi peraturan konservasi dan persyaratan yang ditentukan ncgara pantai atas ZEE mereka.

Dalam kaitan ini Pasal 73 ayat (1) KHL 1982 menentukan bahwa negara pantai untuk keperluan penegakan hukum dapat menaiki, mengadakan inspeksi, melakukan penahanan, melaksanakan proses peradilan. Namun Pasal 73 ayat (3) KHL 1982 tidak membenarkan peraturan negara pantai yang melaksanakan hukuman penjara

\footnotetext{
30 Pasal 11 Peraturan Pemerintah No. 15 Tahun 1984.

31 Pasal 15 Peraturan Pemerintah No. 15 Tahun 1984.

${ }^{32}$ Chairul Anwar, ZEE Di Dalam Hukum Internasional, Sinar Grafika, Jakarta, 1995, hlm 181.
} 
(imprisonment) atau hukurnan badan (corporal punishment).

Baik Undang-undang No. 5 Tahun 1983 tentang Zona Ekonomi Eksklusif Indonesia serta peraturan pelaksanaannya yaitu Peraturan Pernerintah No. 15 Tahun 1984 dan Undang-undang No. 31 Tahun 2004 tentang Perikanan mernuat ketentuan-ketentuan penegakan hukum. Ketentuan-ketentuan penegakan hukum dari Undang-undang No. 5 Tahun 1983 tentang Zona. Ekonomi Eksklusif Indonesia di dalam Pasal 13, Pasal 14, Pasal 15, Pasal 16 dan Pasal 17 mengatur hal-hal sebagai berikut:

1. Penangkapan terhadap kapal-kapal dan atau orang-orang yang diduga melakukan pelanggaran di ZEEI meliputi tindakan penghentian kapal sampai dengan diserahkannya kapal atau orang-orang tersebut di pelabuhan yang di tempat tersebut perkara bersangkutan dapat diproses lebih lanjut.

2. Penyerahan kapal atau orang tersebut harus dilakukan secepat mungkin dan tidak boleh melebihi jangka waktu 7 hari, kecuali dalam, keadaan force majeure.

3. Untuk kepentingan penahanan tindakan pidana yang diatur dalam Pasal 16 dan Pasal 17 termasuk dalarn golongan tindak pidana sebagaimana dimaksud dalam Pasal 21 ayat (4) huruf b Undarig-undang No. 8 Tahun 1981 tentang Kitab Undang-undang Hukurn Acara Pidana.

4. Penegak hukum di bidang penyidikan di ZEEI adalah perwira Tentara Nasional Indonesia Angkatan Laut.
5. Penuntut umum adalah jaksa pada pengadilan negeri bersangkutan.

6. Pengadilan negeri yang mempunyai wewenang mengadili pelanggaran ter hadap ketentuan-ketentuan undang-undang ini adalah pengadilan negeri yang daerah hukumnya meliputi pelabuhan, pada pelabuhan tersebut dilakukan penahanan atas kapal atau orang-orang.

7. Permohonan untuk membebaskan kapal atau orang-orang yang ditangkap dapat dilakukan setiap waktu sebelum ada keputusan dari pengadilan negeri yang berwenang.

8. Permohonan untuk pembebasan kapal dan orang yang ditangkap dapat dikabulkan, jika telah dibayar sejumlah uang jaminan yang layak, ditetapkan oleh pengadilan negeri yang berwenang.

9. Pasal 16 ayat (1) mengancam dengan pidana denda setinggi-tingginya $\mathrm{Rp}$ 250.000.000 bagi mereka yang melakukan tindakan yang bertentangan dengan Pasal 5 ayat (1), Pasal 6, Pasal 7.

Kemudian

Peraturan Pemerintah No. 15 Tahun 1984 di dalam Pasal 17 memuat ketentuan pidana tentang penangkapan ikan tanpa izin di ZEEI yang menunjuk kepada ketentuan pidana dari Undang-undang No. 5 Tahun 1983 seperti telah diuraikan di atas.

Berkaitan dengan politik hukum di bidang perikanan, Pemerintah mengeluarkan Undangundang No. 31 Tahun 2004 tentang Perikanan. Undang-undang ini merupakan pengganti UndangUndang No. 9 Tahun 1985 tentang 
Perikanan. Dengan diberlakukannya Undang-undang perikanan yang baru ini, maka ketentuan tentang pidana denda dalam Pasal 16 ayat (1) Undang-Undang No. 5 Tahun 1983 tentang Zona Ekonomi Eksklusif Indonesia khususnya yang berkaitan dengan tindak pidana di bidang perikanan, dicabut dan dinyatakan tidak berlaku. ${ }^{33}$ Hal ini merupakan suatu langkah maju dalam penanggulangan illegal fishing di ZEEI karena denda yang diancamkan oleh undang-undang ini sangat besar. $^{34}$ Seperti yang telah kita ketahui denda yang selama ini diancamkan jumlahnya sangat sedikit dan tidak sebanding dengan kerugian yang diderita oleh negara akibat tindakan illegal fishing di ZEEI.

Masalah penegakan hukum di ZEEI juga berkaitan dengan masalah KAMLA (Keamanan Laut) dalarn kaitan dengan pelaksanaan "constabulary function". Dalam kaitan dengan KAMLA khusus di bidang perikanan di samping perwira TNI-AL maka pejabat aparatur penegak hukum yang berwenang melakukan penyidikan adalah pejabat pegawai negeri sipil tertentu yang bertugas di bidang perikanan dan Pejabat Polisi Negara Republik Indonesia. ${ }^{35}$

Pejabat pegawai negeri sipil bidang perikanan tersebut mempunyai kewenangan:

1. Menerima laporan tentang adanya pelanggaran.

33 Pasal 110 (b) Undang-Undang No. 31 Tahun 2004 tentang Perikanan.

${ }^{34}$ Ancaman denda dalam undang-undang ini berkisar antara Rp. 250.000.000,00 ( dua ratus lima puluh juta rupiah ) sampai dengan Rp. 20.000.000.000,00 ( dua puluh miliar rupiah ).

35 Pasal 72 Undang-Undang No. 31 Tahun 2004 tentang Perikanan.
2. Melakukan pemanggilan dan pemeriksaan terhadap tersangka pelaku pelanggar ketentuan Undang-undang No. 31 Tahun 2004.

3. Menggeledah kapal perikanan, sarana angkutan dan tempat menyimpan, mendinginkan dan mengawetkan ikan yang diduga dipergunakan dalam atau menjadi tempat melakukan pelanggaran ketentuan Undang-undang No.31 Tahun 2004

4. Melakukan penyitaan ikan yang dihasilkan, alat-alat serta surat-surat yang digunakan dalam melakukan perbuatan yang melanggar ketentuan Undangundang No. 31 Tahun 2004.

Selanjutnya upaya-upaya yang perlu ditempuh dalam rangka pengamanan perikanan ialah menerapkan prinsip-prinsip pengaturan sumber daya ikan dengan Pendekatan biologis yang mengandung langkah preventif, kuratif yang dikenal sebagai sistem "Monitoring, Control and Surveillance" (MCS). Hingga dewasa ini yang baru dilakukan adalah sebagian dari "control" yang masih memerlukan penyempurnaan. Upaya-upaya "monitoring" yang meliputi pengisian formulir tentang data produksi, alat tangkap, daerah operasi dan memberi tanda pada kapal dengan warna/ kode tertentu, wajib lapor belum berjalan efektif. Kewajiban untuk memberikan tanda pada kapal perikanan asing yang beroprasi di ZEEI juga belum sepenuhnya dipatuhi. Di bidang perikanan sudah saatnya diterapkan sistem pengawasan perikanan yang lebih intensif dengan penerapan sistem MCS. Adapun sasaran daripada "monitoring" ialah untuk mengetahui setiap perubahan di 
dalam kepadatan pemanfaatan sumber perikanan dan untuk mencegah penangkapan ikan yang berlebihan. Di ZEEI asesmen stok dan pengawasan atas kegiatan perikanan akan lebih sulit dan kompleks dibandingkan dengan bagian bagian lain dari perairan Indonesia, oleh karena ZEEI adalah laut terbuka. ${ }^{36}$

Sifat-sifat stok dan seluruh kegiatan yang sudah ada di ZEEI yang merupakan kawasan laut yurisdiksi yang baru, menimbulkan beberapa kesulitan di dalam evaluasi dari sumber perikanan. Masalah ini dapat diatasi dengan melalui upaya "monitoring" agar dapat mengikuti gerak-gerik kegiatan dan keadaan yang tidak terduga dari sumber perikanan. ${ }^{37}$

Data Yang diperoleh dari riset perikanan dan dari survei pada umumnya meliputi: ${ }^{38}$

1. kepadatan stok

2. komposisi spesies

3. distribusi

4. tangkapan rata-rata

5. faktor lingkungan.

$\begin{array}{cccr}\text { Hasil } & \text { riset } & \text { dan survei } \\ \text { diperlukan } & \text { untuk } & \text { mengadakan }\end{array}$ evaluasi dari sumber perikanan yang diamati untuk memperoleh kesimpulan menyeluruh dari surnber perikanan. Selanjutnya control adalah merupakan kunci dari manajemen perikanan yang sukses. Dengan mempergunakan mekanisme "control" kegiatan-kegiatan penangkapan ikan yang sah dan yang tidak sah dapat dikenali dan diadakan deteksi. ${ }^{39}$

36 Chairul Anwar, ZEE Di Dalam Hukum Internasional, Opcit, hlm 185.

${ }^{37}$ Ibid.

38 Ibid.

39 Ibid.
"Control" juga merupakan upaya untuk implementasi dari kebijaksanaan Perikanan. Kapal Perikanan diharuskan beroperasi sesuai dengan keadaan yang didasarkan pada kebijaksanaan tersebut. Dalam melakukan "control" terhadap kapal perikanan asing yang beroperasi di ZEEI, lisensi dapat digunakan sebagai alat melakukan "control", dengan. menentukan persyaratan dari peraturan pernerintah pada lisensi tersebut yang harus dipatuhi oleh kapal perikanan. ${ }^{40}$

Kemudian surveillance adalah suatu komponen pengumpulan data intelijen yang penting dari rezim manajemen. Dengan "surveillance" kegiatan-kegiatan penangkapan ikan tidak sah (illegal fishing) kapal perikanan asing akan ditemukan. Dalam kaitan ini "surveillance" adaIah langkah pertama dari proses penegakan hukum. Badan yang bertanggung jawab adalah Badan Koordinasi Keamanan Laut (BAKORKAMLA) yang dibentuk dengan SK Menteri Pertahanan/Keamanan, Menteri Perhubungan, Menteri Keuangan, Menteri Kehakiman dan Jaksa Agung tanggal 19 Desember 1972. ${ }^{41}$

Sasaran dari "surveillance" di dalam manajemen perikanan adalah untuk memperoleh pengetahuan tentang kegiatan perikanan di dalam perairan yang berada di bawah yurisdiksi RI untuk memastikan agar kegiatan kapal perikanan mengikuti peraturan-peraturan yang berlaku. adalah: ${ }^{42}$

Fungsi dari "surveillance"

1. Mengamati kapal perikanan yang beroperasi secara tidak sah.

\footnotetext{
${ }^{40}$ Ibid, hlm 186.

${ }^{41}$ Ibid.

${ }^{42}$ Ibid.
} 
2. Mengamati kapal riset yang bekerja secara tidak sah.

3. Melakukan inspeksi atas alat tangkap yang dipakai apakah sesuai dengan ketentuan lisensi.

4. Memberikan bantuan atas kapal dalam musibah.

Di dalam kawasan laut ZEE yang luas, "surveillance" dan penegakan hukum perikanan meliputi penetapan JTB, pembatasan kawasan laut, musim tangkapan ikan, penentuan spesies ikan yang bileh ditangkap, jenis dari alat tangkap yang boleh dipakai, sistem laporan hasil tangkapan ikan, dan laporan posisi kapal perikanan. "Control" dan "surveillance" dari kawasan laut seluas 200 mil menghendaki negara pantai harus menyediakan personil yang terlatih baik serta dana yang diperlukan untuk pembelian dan operasi dari kapal-kapal patroli, pesawat terbang pengintai, radar pantai dan peralatannya. Kegiatan tersebut akan melindungi nelayan lokal terhadap penangkapan ikan tidak sah dari kapal perikanan asing.

Selain hal-hal tersebut di atas, sistem pengendalian dan pengawasan terhadap kapal-kapal perikanan yang melakukan kegiatan penangkapan dan pengangkutan ikan adalah dengan sistem jasa satelit yang dikenal dengan Vessel Monitoring System (VMS) dan Teknologi Komunikasi Maju. Dengan implementasi MCS berbasis teknologi ini dapat diperoleh manfaat sebagai berikut: ${ }^{43}$

1. Keberadaan kapal-kapal ikan yang berlayar di wilayah perairan Indonesia dapat terpantau.

43 Eddy Prahasta, Monitoring Controlling and Surveillance ( $M C S$ ), Disampaikan pada Seminar Nasional ( ITB Ocean Expo ) Pengembangan Infrastruktur Maritim Indonesia, Bandung, 2000.
2. Potensi perikanan laut Indonesia dapat dimonitor dan digali secara optimal, untuk kebutuhan yang lebih jauh lagi, sistem ini dapat dimanfaatkan untuk program konservasi sumber daya perikanan laut.

3. Informasi penangkapan ikan dapat segera diperoleh dengan cepat melalui teknologi internet dari manapun.

4. Aktivitas-aktivitas pelayaran di perairan Indonesia dapat dipantau oleh institusi yang berwenang.

Lebih lanjut berkaitan dengan penegakan hukum ini Mochtar Kusumaatmadja meyetakan bahwa aspek penegakan hukum merupakan aspek penting di ZEE, karena tanpa penegakan hukum, hak-hak berdaulat dan yurisdiksi yang dimiliki menjadi tidak ada artinya. Berkaitan dengan hal ini Mochtar Kusumaatmadja memperinci kewenangankewenangan yang dimiliki oleh aparat penegak hukum, yakni : ${ }^{44}$

1. Menangkap dan menaiki kapalkapal ikan di zona 200 mil, untuk melakukan pemeriksaan peralatan, awak kapal, hasil tangkapan, surat ijin, sertifikat dan dokumen-dokumen lainnya.

2. Kapal ikan asing yang diduga telah melakukan pelanggaran di zona ini aparat penegak hukum mempunyai kewenangan untuk melakukan pengejaran seketika (hot pursuit) ${ }^{45}$ yang dikenal

44 Mochtar Kusumaatmadja, Beberapa Masalah Pokok Sekitar Pengumuman Tentang Zona Ekonomi Eksklusif Indonesia, Majalah Hukum dan Pembangunan, Tahun X No. 4, 1990, hlm 389-390.

${ }^{45}$ Hot Pursuit adalah pengejaran sacara sah dari kapal asing di laut lepas sebagai akibat pelanggaran terhadap perundang-undangan negara yang melakukan pengejaran. Menurut D.P. O' Connel dalam bukunya “ The International Law of The Sea", istilah 
dalam hukum internasional, untuk melakukan pengejaran seketika secara mutatis mutandis di ZEE negara pantai. Pengejaran seketika berakhir jika kapal yang dikejar memasuki laut lepas atau ZEE negara ketiga.

3. Melakukan pengujian atau pemeriksaan ikan di laut atau di darat.

4. Mengambil contoh hasil tangkapan untuk pemeriksaan.

5. Menahan kapal ikan berikut awaknya, ataupun orang yang bertanggung jawab atau yang terlibat pelanggaran di ZEE, penahanan dapat dibebaskan dengan uang jaminan atau cara pengamanan lain atau harus diberitahukan kepada negara bendera kapal melalui jalur diplomatic.

6. Tidak diberlakukan hukuman penjara.

7. Melakukan penyitaan terhadap kapal ikan dan perlengkapannya termasuk alat tangkap yang digunakan dalam pelanggaran tersebut.

8. Melakukan penyitaan hasil tangkapan atau muatan kapal yang merupakan hasil tindakan pelanggaran tersebut.

9. Melakukan penyitaan terhadap bahan peledak atau alat lainnya yang membahayakan, yang diduga digunakan dalam penangkapan ikan secara tidak sah tersebut.

\section{e. Bentuk-bentuk Pelanggaran Hukum di Zona Ekonomi Eksklusif Indonesia}

Indonesia dalam upaya menanggulangi illegal fishing ini, nampaknya lebih mengedepankan pada aspek perijinan untuk menanggulangi illegal fishing oleh kapla ikan asing di wilayah ZEEI. Dengan demikian tindakan-tindakan pelanggaran yang sering terjadi tentu saja tindakan pelanggaran di bidang perijinan. Berikut bentuk-bentuk tindak pelanggaran yang sering terjadi di bidang perijinan $:^{46}$

1. Pelanggaran terhadap jalur penangkapan, di mana jalur atau posisi daerah operasi yang tertera dalam dokumen perijinan tidak diindahkan atau ditepati.

2. Alat penangkapan yang digunakan tidak sesuai dengan yang tertera dalam dokumen perijinan.

3. Masih melakukan aktivitas meskipun dokumen perijinannya sudah kadaluarsa.

4. Melakukan pendaratan atau bongkar muat di tempat yang bukan pangkalannya.

5. Tidak melakukan kewajiban melapor kepada Dinas Perikanan setempat ataupun melaporkan Bukti Pengiriman Ekspor.

Kemudian bentuk lain dari pelanggaran penangkapan ikan di wilayah ZEEI adalah kapal ikan asing yang sengaja melakukan penangkapan ikan di ZEEI, artinya kapal ikan asing yang sengaja masuk ke wilayah ZEEI tanpa membawa

\footnotetext{
46 Direktorat Jenderal Perikanan RI, Implementasi VMS Dalam Rangka Pengelolaan Laut Lestari Ditinjau Dari Aspek Perijinan, Makalah disampaikan pada Seminar Peringatan Hari Nusantara Tahun 2000, tanggal 9 Nopember 2000, hlm 3.
} 
Surat Ijin Penangkapan Ikan ( SIPI ) dari Pemerintah Republik Indonesia.

f. Kendala-Kendala Yang Dihadapi Oleh Indonesia Dalam Menanggulangi Penangkapan Ikan Secara Tidak Sah (Illegal Fishing) oleh Kapal Ikan Asing Di Zona Ekonomi Eksklusif Indonesia

Berikut kendala-kendala yang dihadapi oleh Indonesia dalam menanggulangi illegal fishing di wilayah ZEEI :

1. Luasnya wilayah ZEEI yang membutuhkan sarana dan prasarana yang cukup serta dana yang besar.

2. Ketiadaaan satu garis komando dalam menegakkan hukum di wilayah laut Indonesia mengakibatkan potensi laut belum bisa dimanfaatkan secara efektif. Penegakan hukum oleh berbagai instansi pemerintah saat ini sangat sektoral sehingga perlu segera dibentuk undang-undang yang mengatur pengamanan laut di bawah satu komando. meskipun ada Badan Koordinasi Kemanan Laut (Bakorkamla) namun kedudukannya saat ini tidak kuat karena hanya diatur oleh surat kesepakatan bersama (SKB). Padahal, SKB itu tidak memiliki kedudukan yang kuat di dalam hukum. Pengamanan bersama seperti itu perlu diatur oleh undang-undang sehingga kedudukannya benar-benar kuat. pembagian tugas dan wewenang antara TNI AL, Polri, dan Penyidik Pegawai Negeri Sipil tidak jelas, hal ini menyebabkan Mereka seolah memiliki hak untuk menegakkan hukum di laut secara sendiri-sendiri. ${ }^{47}$

3. Belum efektifnya pelaksanaan MCS selama ini, karena MCS baru dilakukan sebatas pengawasan terhadap ijin, sedangkan kapal ikan asing yang melakukan penangkapan ikan secara tidak sah tidak terpantau. Di samping itu " control" dan "surveillance" dari kawasan laut seluas 200 mil menghendaki negara untuk harus menyediakan personil yang terlatih baik serta dana yang diperlukan untuk pembelian dan operasi dari kapalkapal patroli, pesawat terbang pengintai, radar pantai, dan peralatan lainnya. ${ }^{48}$ Indonesia memiliki keterbatasan untuk menyediakan dan mempergunakan peralatan tersebut secara terus- menerus.

\section{PENUTUP}

\subsection{Simpulan}

1. Indonesia berdasarkan KHL tahun 1982 mempunyai kewenangan yang tegas secara hukum internasional dalam menanggulangi tindak illegal fishing oleh kapal ikan asing di wilayah ZEE. Kewenangan tersebut, yakni :

\footnotetext{
${ }^{47}$ Etty Roesmaryati Agoes, Sepuluh Tahun Berlakunya Konvensi PBB tentang Hukum Laut (Unclos) 1982: Kewajiban Negara Peserta dan Implementasinya oleh Indonesia, Pidato Pengukuhan Sebagai Guru Besar Ilmu Hukum Fakultas Hukum Universitas Padjajaran, Bandung, tanggal 18 September 2004.

${ }^{48}$ Berhubung kapal perikanan selalu dalam keadaan bergerak, hal ini menyebabkan tugas "surveillance" dan inspeksi merupakan tugas yang berat. Penegakan hukum dari peraturan perikanan pada kawasan laut 200 mil adalah tugas yang cukup sulit.
} 
a. Menaiki, melakukan inspeksi, menahan, dan mengajukan ke pengadilan kapal beserta awak-awaknya.

b. Bahwa kapal beserta awaknya yang ditahan akan segera dibebaskan setelah dilakukan pembayaran uang jaminan.

c. Melakukan penahanan kapal-kapal asing, tetapi harus segera memberi tahu negara bendera kapal atas tindakan yang diambil dan denda yang dikenakan.

Namun, dalam pelaksanaan penegakan hukumnya tidak dibenarkan untuk melaksanakan hukuman penjara (imprisonment) atau hukuman badan (corporal punishment), yang boleh dijatuhkan hanyalah pidana berupa denda.

2. Upaya-upaya dalam penanggulangan tindak illegal fishing di ZEEI masih mengalami hambatan yang disebabkan oleh beberapa faktor, yakni :

a. Lemahnya penegakan hukum yang dapat dilakukan oleh pemerintah Indonesia.

b. Luasnya wilayah ZEEI sehingga membutuhkan sarana dan prasarana yang cukup untuk mengadakan pengawasan (dalam bidang polisional) di wilayah ZEEI.

c. Penanggulangan illegal fishing ini lebih ditekankan pada aspek perijinan, sehingga kapal ikan asing yang sengaja melakukan tindak illegal fishing di ZEEI sulit untuk dijangkau atau luput dari pengawasan aparat penegak hukum Indonesia.

Sedangkan khusus untuk sanksi yang dijatuhkan, yang menurut banyak pihak tidak sebanding dengan jumlah kerugian yang diderita oleh negara akibat illegal fishing, sudah direspons dalam politik hukum perikanan Indonesia, yaitu dengan cara mengganti Undang-Undang No. 9 Tahun 1985 tentang Perikanan dengan Undang-Undang tentang Perikanan yang baru (UndangUndang No. 31 Tahun 2004 tentang Perikanan). Lahirnya Undangundang ini selain menggantikan Undang-Undang No. 9 Tahun 1985, juga mencabut dan menyatakan tidak berlaku ketentuan tindak pidana denda dalam Pasal 16 ayat (1) Undang-Undang No. 5 Tahun 1983 tentang Zona Ekonomi Eksklusif Indonesia. Namun hal ini masih harus diperhatikan terus dalam tingkat pelaksanaannya.

\subsection{Saran}

Tindakan-tindakan yang dapat diambil dalam rangka menanggulangi illegal fishing di wilayah ZEEI adalah :

1. Mengadakan perjanjian perikanan dengan negara-negara yang nelayannya terbukti banyak menangkap ikan secara tidak sah di ZEEI. Perjanjian ini diadakan dalam rangka bekerjasama dalam hal melakukan penegakan hukum terhadap pelaku tindak illegal fishing di ZEEI. Di samping itu dengan adanya perjanjian dengan negara yang bersangkutan maka 
dapat dijatuhkan hukuman maksimal terhadap pelaku, sehingga dapat dijadikan upaya preventif dalam hal penegakan hukum di bidang perikanan.

2. Meningkatkan kemampuan TNI AL dalam rangka menjalankan tugasnya sebagai penjaga keamanan di wilayah laut. Peningkatan kemampuan tersebut, baik dari segi aparatnya juga dari segi peralatannya.

3. Mengembangkan dan meningkatkan sistem pengawasan ( MCS ) yang lebih efektif terutama terhadap kapalkapal yang sengaja melakukan tindak illegal fishing di ZEEI, sehingga saat ini yang penting untuk dikembangkan dan ditingkatkan adalah sistem pengawasan yang dilakukan dengan bantuan satelit.

\section{DAFTAR PUSTAKA}

Buku, orasi ilmiah, makalah, artikel

Albert W. Koers, Konvensi Perserikatan Bangsa-Bangsa Tentang Hukum Laut Suatu Ringkasan, diterjemahkan oleh Rudi M. Rizki dan Wahyuni Bahar, Gadjah Mada University Press, Yogyakarta, 1994.

Chairul Anwar, Horizon Baru Hukum Laut Internasional, Djambatan, 1989.

.............., ZEE Di Dalam Hukum Internasional, Sinar Grafika, Jakarta, 1995.

D. P. O' Connel, The International Law of The Sea, Volume I, Clarendon Press, London, 1988.

Departemen Kelautan dan Perikanan RI, Kampanye Kelautan dan
Perikanan

(Paradigma

Pembangunan Kelautan dan Perikanan), Yayasan Bina Mulia, Jakarta, 2000.

Direktorat Jenderal Perikanan RI, Implementasi VMS Dalam Rangka Pengelolaan Laut Lestari Ditinjau Dari Aspek Perijinan, Makalah Disampaikan pada Seminar Peringatan Hari Nusantara Tahun 2000, Tanggal 9 Nopember 2000.

Etty R. Agoes, Pemanfaatan Sumber Daya Kelautan dan Tantangan Liberalisasi Ekonomi Dalam Menghadapi Era Perdagangan Bebas, Makalah Disampaikan Pada Seminar Konvensi Nasional Pembangunan Benua Maritim Indonesia Dalam Rangka Mengaktualisasikan Wawasan Nusantara, Ujung Pandang, 1819 Desember 1996

.................. Sepuluh Tahun
Berlakunya Konvensi PBB
tentang Hukum Laut (Unclos)
1982: Kewajiban Negara Peserta dan Implementasinya oleh Indonesia, Pidato Pengukuhan Sebagai Guru Besar Ilmu Hukum Fakultas Hukum Universitas Padjajaran, Bandung, tanggal 18 September 2004.

Eddy Prahasta, Monitoring Controlling and Surveillance (MCS), Disampaikan pada Seminar Nasional ( ITB Ocean Expo 2000 ) Pengembangan Infrastruktur Maritim Indonesia, 2000.

Frans E. Likadja, Bunga Rampai Hukum Laut Internasional, Bina Cipta, Bandung, 1978.

F. Sugeng Istanto, Hukum Internasional, Penerbitan Universitas Atma Jaya Yogyakarta, Yogyakarta, 1995. 
H.A.S. Natabaya,et. All, AspekAspek Hukum Pengelolaan Perikanan Di Perairan Nasional Zona Ekonomi Eksklusif Indonesia, BPHN, Jakarta, 1993.

Hotman Sitorus, Mengkaji Ulang Sanksi Pidana Di Zona Ekonomi Eksklusif, dimuat dalam Harian Neraca, Kamis 4 Maret 1993.

Mochtar Kusumaatmadja, Beberapa Masalah Pokok Sekitar Pengumuman Tentang Zona Ekonomi Eksklusif Indonesia, Majalah Hukum dan Pembangunan, Tahun $\mathrm{X}$ No. 4, 1990.

Mustafa Abdullah, Aspek Hukum Penerapan KUHAP di Perairan Indonesia dan Zona Ekonomi Eksklusif, BPHN, Jakarta, 1998.

P. Joko Subagyo, Hukum Laut Indonesia, Rhineka Cipta, Jakarta, 1993, hlm 98.

Rusmana, Pengadilan Perikanan Mampukah Menjadi Terobosan, Solusi hukum.com, 30 Oktober 2004.

Syahmin A.K, Beberapa Perkembangan dan Masalah Hukum Laut Internasional (Sekitar Penegakan Hukum di Perairan Yurisdiksi Nasional Dewasa Ini), Bina Cipta, Bandung.

\section{$\underline{\text { Konvensi-Konvensi Internasional }}$}

Vienna Convention on The Law of Treaties 1969

United Nations Convention on the Law of the Sea 1982

\section{$\underline{\text { Peraturan Perundang-undangan }}$}

Undang-Undang No. 8 Tahun 1981 tentang Hukum Acara Pidana.
Undang-Undang No. 5 Tahun 1983 tentang Zona Ekonomi Eksklusif Indonesia.

Undang-Undang No. 17 Tahun 1985 tentang Pengesahan United Nations Convention on The Law of The Sea (Konvensi Perserikatan Bangsa-Bangsa Tentang Hukum Laut).

Undang-Undang No. 9 Tahun 1985 tentang Perikanan.

Undang-Undang No. 31 Tahun 2004 tentang Perikanan.

Peraturan Pemerintah No. 15 Tahun 1984 tentang Pengelolaan Sumber Daya Alam Hayati Di Zona Ekonomi Eksklusif Indonesia.

SK Menteri Pertahanan/Keamanan, Menteri Perhubungan, Menteri Keuangan, Menteri Kehakiman dan Jaksa Agung tanggal 19 Desember 1972. 